\title{
PERBEDAAN TARIF ASUHAN KEHAMILAN DAN PERSALINAN ANTARA PESERTA BPJS KESEHATAN DAN NON-BPJS KESEHATAN
}

\author{
The Differences of Pregnancy and Childbirth Care Tariff between Member and Non- \\ Member of Indonesia Universal Health Coverage
}

\author{
Astri Nurdiana*, Ella Nurlailasari \\ Program Studi D3 Kebidanan Fakultas Ilmu Kesehatan \\ (astri.nurdiana@fikes.unsika.ac.id/085694957777)
}

\begin{abstract}
ABSTRAK
Pemberlakuan jaminan kesehatan nasional yang diselenggarakan melalui Badan Penyelenggara Jaminan Sosial mengalami berbagai polemik salah satunya berkaitan dengan pembiayaan pada penyedia pelayanan asuhan kebidanan yang tercantum pada Permenkes No 52 tahun 2016 tentang standar tarif pelayanan kesehatan dalam program jaminan kesehatan, apakah standarisasi tarif tersebut dapat menutup kebutuhan palayanan yang diberikan oleh bidan baik di pedesaan ataupun diperkotaan atau tidak. Penelitian ini merupakan penelitian analitik komparatif tarif 2 kelompok tidak berpasangan yaitu tarif non BPJS Kesehatan di perkotaan dan di pedesaan yang kemudian dibandingkan dengan standar tarif yang telah ditetapkan oleh BPJS Kesehatan. Ditemukan hasil bahwa tidak terdapat perbedaan tarif asuhan kehamilan antara di perkotaan dan pedesaan ( $p>0,05)$, namun terdapat perbedaan tarif asuhan kehamilan antara tarif di perkotann dan tarif BPJS $(p<0,05)$, untuk tarif asuhan persalinan normal dan dengan kondisi kegawatan ditemukan perbedaan yang signifikan antara standar tarif BPJS Kesehatan dan tarif yang ditetapkan oleh bidan $(\mathrm{p}<0,05)$.
\end{abstract}

Kata kunci: Evaluasi, Bidan, BPJS, Tarif, Kesehatan

\begin{abstract}
Enforcement of national health insurance organized through Badan Penyelenggara Jaminan Kesehatan experiences various polemics, one of which relates to financing for midwifery care listed in Permenkes No. 52 of 2016 concerning health service fare standards in the health insurance program, whether the standard tariff can cover the needs of services provided by midwives in rural or urban areas or not. esult found that there is no difference in antenatal care tariff between urban and rural areas ( $p>0.05)$, while there are differences in antenatal care tariff between urban tariff and UHC tariff standard $(p<0.05)$, additionally there are significant different between both normal and childbirth with emergency condition tariff of UHC and urban and rural areas tariff $(p<0.05)$
\end{abstract}

Keywords: Evaluation, BPJS, Midwife, Tariff, Health 


\section{PENDAHULUAN}

Kehidupan sehat dan sejahtera merupkan salah satu dari 17 tujuan pembangunan berkelanjutan atau Sustainable Development Goals (SDG), SDG diberlakukan dengan prinsip universal, integrasi dan inklusif untuk meyakinkan bahwa tidak ada seorangpun yang terlewatkan atau No-one left behind (Bapennas, 2017).

Pelayanan kesehatan yang adil dan merata merupakan harapan seluruh masyarakat Indonesia, Schröders et al (2017) dalam hasil kajiannya menyebutkan bahwa ketidakadilan dalam pelayanan kesehatan antara masyarakat pedesan dan perkotaan terjadi secara nyata di Indonesia, yang menyebabkan tidak semua masyarakat pedesaan mendapatkan pelayanan yang optimal seperti masyarakat yang tinggal di perkotaan (Schröders et al., 2017).

Pemerintah Indonesia secara terus menerus melakukan upaya pemerataan peayanan kesehatan, hal ini diwujudkan dengan adanya kebijakan pemerintah dengan penerapan jaminan kesehatan nasional. BPJS kesehatan merupakan transformsi dari PT. Askes, transformasi tersebut berlangsung sejak November 2011 hingga 31 Desember 2013, sehingga PT Askes secara resmi dinyatakan bubar dan dilanjutkan dengan implementasi BPJS
Kesehatan yang dilakukan sejak 1 Januari 2014 (BPJS Kesehatan, 2017).

BPJS Kesehatan memeiliki kewenangan publik yang ditetapkan dalam Undangundang yaitu menyelenggarakan kepentingan jaminan sosial nasional berdasarkan asas kemanusiaan, manfaat dan keadilan sosial bagi seluruh rakyat Indonesia, selain itu BPJS kesehatan diberikan kewenangan untuk membuat aturan yang mengikat umum serta bertugas untuk mengelola dana public (BPJS Kesehatan, 2017).

Dalam realisasinya BPJS kesehatan menemukan banyak konflik di masyarakat, salah satunya konflik yang berkaitan dengan penyedia pelayanan kesehatan, surat kabar Pikiran Rakyat menyebutkan bahwa hingga saat ini BPJS Kesehatan telah merugikan sekitar 2400 rumah sakit mitra BPJS Kesehatan. Sejalan dengan hal tersebut media online CNN menyebutkan bahwa di awal implementasinya BPJS Kesehatan telah mengalami defisit anggaran sebesar Rp. 3,3 triliun, meningkat menjadi Rp.5,7 triliun di tahun 2015, Rp. 9,7 triliun di tahun 2016, Rp. 9,75 triliun di tahun 2017 dan Rp. 10,98 triliun di tahun 2018 (Gumelar, 2018).

Pada era JKN ini bidan berkontribusi dalam memberikan asuhan kebidanan secara menyeluruh dan merata karena bidan dapat 
melakukan jejaring dengan fasilitas pelayanan kesehatan tingkat pertama untuk dapat melayanan peserta BPJS. Sehingga selain mengatur tentang tarif pelayanan kesehatan di tingkat pertama dan tingkat rujukan, BPJS kesehatan mengatur pula tarif pelayanan kehamilan, persalinan, nifas dan bayi baru lahir yang dilakukan oleh bidan, sebagaimana yang tercantum pada Permenkes No 52 tahun 2016 tentang standar tarif pelayanan kesehatan dalam program jaminan kesehatan dengan rincian tarif pelayanan sebagai berikut:(Indonesia, 2016)

1. Pemeriksaan ANC sesuai standar diberikan dalam bentuk paket paling sedikit sebanyak 4 kali pemeriksaan yaitu sebesar Rp. 200.000, jika pemeriksaan ANC tidak dilakukan di satu tempat maka pemeriksaan dibayar sebesar Rp.50.000

2. Persalinan pervaginam normal yang dilakukan oleh bidan dibayar sebesar Rp.700.000

Pembiayaan jaminan kesehatan merupakan hal yang sangat krusial menentukan kualitas pelayanan kesehatan yang diberikan, pembiayaan jaminan kesehatan haruslah bepihak pada kedua sisi dalam system pelayanan kesehatan yaitu tenaga kesehatan sebagai pemberi pelayanan dan pasien sebagai penerima pelayanan. Tidak hanya di Indonesia aspek keadilan dalam pembiayaan kesehatan merupakan isu yang berkembang di negara dengan jumlah pertumbuhan penduduk yang tinggi yaitu India.

Pembiayaan sistem kesehatan berdampak pada permasalahan keuangan yang dihadapi oleh pemberi pelayanan kesehatan. Hasil studi yang dipublikasikan dalam jurnal yang berjudul "Who pays for healthcare in Bangladesh? An analysis of progressivity in health system financing" didapatkan bahwa pembayaran biaya kesehatan yang dibayarkan kepada tenaga kesehatan jauh dibawah standar konsumsi kebutuhan utama masyarakat di India, hal itu diukur berdasarkan 3 variabel yaitu pembiayan konsumsi makanaan, pembiayaan konsumsi selain makanan dan pembiayaan pelayanan kesehatan (Molla \& Chi, 2017).

Penelitian ini bertujuan untuk mengevaluasi kebijakan tarif asuhan kehamilan dan persalinan berdasarkan Permenkes No 52 tahun 2016 tentang standar tarif JKN yang dibandingan dengan tarif umum yang diberlakukan oleh bidan. Manfaat dari penelitian ini adalah untuk evaluasi implementasi tarif asuhan kehamilan dan persalinan peserta BPJS Kesehatan yang dilakukan oleh bidan di Kabupaten Karawang dan Identifikasi tarif asuhan kehamilan dan persalinan berdasarkan wilayah pedesaan dan perkotaan di Kabupaten Karawang. 


\section{METODE}

Penelitian ini merupakan penelitian analitik komparatif membangdingkan tarif 2 kelompok tidak berpasangan yaitu tarif non BPJS Kesehatan di perkotaan dan di pedesaan yang kemudian dibandingkan dengan standar tarif yang telah ditetapkan oleh BPJS Kesehatan. Pengumpulan data dilakukan melalu survey langsung pada bidan yang dijadikan responden penelitian, Populasi penelitian merupakan seluruh bidan yang ada di 50 wilayah kerja di Kabupaten Karawang yaitu sebanyak 864, dan berdasarkan hasil penghitungan sampel minimal 31 bidan yang dijadikam sebagai subjek untuk setiap kelompok penelitian.
Penentuan 31 subjek penelitian di 50 wilayah kerja di Kabupaten Karawang dilakukan melalui purposive sampling dipilih bidan yang berjejaring dengan BPJS Kesehatan di wilayah pedesan dan bidan di wilayah perkotaan. 50 wilayah kerja tersebut diklasifikasikan menjadi wilayah pedesaan jika wilayah tersebut belum memenuhi klasifikasi kriteria wilayah perkotaan berdasarkan peraturan kepala Badan Pusat Statistik No 37 tahun 2010. sehingga 50 wilayah kerja puskesmas di Kabupaten Karawang diklasifikasikan pada tabel 1 (Statistik, 2018).

Tabel 1 Klasifikasi Wilayah di Kabupaten Karawang

\begin{tabular}{|c|c|c|}
\hline No & Wilayah Kerja & Klasifikasi \\
\hline 1. & Pangkalan & Pedesaan \\
\hline 2. & Loji & Pedesaan \\
\hline 3. & Ciampel & Pedesaan \\
\hline 4. & Teluk Jambe & Perkotaan \\
\hline 5. & Wadas & Perkotaan \\
\hline 6. & Wanakerta & Pedesan \\
\hline 7. & Klari & Perkotaan \\
\hline 8. & Curug & Perkotaan \\
\hline 9. & Anggadita & Perkotaan \\
\hline 10. & Cikampek & Perkotaan \\
\hline 11. & Purwasari & Pedesaan \\
\hline 12. & Tirtamulya & Pedesaan \\
\hline 13. & Jatisari & Perkotaan \\
\hline 14. & Pacing & Pedesaan \\
\hline 15. & Cicinde & Perkotaan \\
\hline 16. & Gempol & Perkotaan \\
\hline 17. & Kotabaru & Perkotaan \\
\hline 18. & Jomin & Perkotaan \\
\hline 19. & Cikampek Utara & Perkotaan \\
\hline 20. & Cilamaya & Perkotaan \\
\hline 21. & Sukatani & Perkotaan \\
\hline 22. & Pasirukem & Pedesaan \\
\hline 23. & Bayur Lor & Pedesaan \\
\hline 24. & Lemahabang & Perkotaan \\
\hline 25. & Talagasari & Perkotaan \\
\hline 26. & Majalaya & Pedesaan \\
\hline 27. & Plawad & Pedesaan \\
\hline 28. & Adiarsa & Perkotaan \\
\hline 29. & Karawang & Perkotaan \\
\hline
\end{tabular}




\begin{tabular}{|c|c|c|}
\hline No & Wilayah Kerja & Klasifikasi \\
\hline 30. & Karawang Kota & Perkotaan \\
\hline 31. & Tunggakjati & Perkotaan \\
\hline 32. & Nagasari & Perkotaan \\
\hline 33. & Tanjungpura & Perkotaan \\
\hline 34. & Rawamerta & Pedesaan \\
\hline 35. & Balongsari & Perkotaan \\
\hline 36. & Tempuran & Perkotaan \\
\hline 37. & Lemah Duhur & Pedesaan \\
\hline 38. & Kutawaluya & Perkotaan \\
\hline 39. & Kutamukti & Perkotaan \\
\hline 40. & Rengasdengklok & Perkotaan \\
\hline 41. & Kalangsari & Perkotaan \\
\hline 42. & Medangasem & Perkotaan \\
\hline 43. & Jayakerta & Pedesaan \\
\hline 44. & Pedes & Pedesaan \\
\hline 45. & Sungaibuntu & Pedesaan \\
\hline & Kertamukti & Pedesaan \\
\hline 47. & Cibuaya & Pedesaan \\
\hline 48. & Tirtajaya & Pedesaan \\
\hline 49. & Batujaya & Pedesaan \\
\hline 50. & Pakisjaya & Pedesaan \\
\hline
\end{tabular}

Kriteria inklusi pada penelitian ini adalah bidan yang memiliki praktik mandiri dan memberikan pelayanan kebidanan baik pada pasien peserta JKN maupun non peserta JKN, kriteria eksklusi untuk penelitian ini yaitu jika bidan mengisi kuesioner penelitian dengan tidak jelas atau salah satu pertanyaan tentang tarif tidak diisi. Jumlah sampel yang didapatkan sebanyak
37 data tarif BPJS Kesehatan, 36 data tarif nonBPJS Kesehatan di pedesaan dan 38 data tarif non-BPJS kesehatan di perkotaan.

Analisis data penelitian merupakan analisis komparatif tidak berpasangan menggunakan Uji Kruskal-Wallis, Uji post hoc menggunakan Mann-Whitney . Hasil survei tarif pelayanan kebidanan di PMB dimasukan dalam tabel 2

Tabel 2 Tarif Asuhan Kebidanan

\begin{tabular}{cllc}
\hline Bidan/Kecamatan & \multicolumn{1}{c}{ Jenis Pelayanan } & \multicolumn{1}{c}{ Tarif BPJS } & Tarif Non BPJS \\
\hline Nama bidan..... & $\begin{array}{l}\text { Pemeriksaan Kehamilan } \\
\text { Persalinan }\end{array}$ & $\begin{array}{l}\text { Rp. 50.000 } \\
\text { Rp. 700.000 }\end{array}$ & $\begin{array}{c}\text { Tarif yang } \\
\text { diberlakukan di } \\
\text { Bidan.... }\end{array}$ \\
& $\begin{array}{l}\text { Persalinan dengan } \\
\text { kegawatdaruratan }\end{array}$ & Rp. 700.000 & \\
\hline
\end{tabular}

\section{HASIL}

\section{Gambaran Lokasi Penelitian}

Karawang merupakan salah satu provinsi di Jawa Barat dengan luas wilayah 1.753,27 km2, Kabupaten yang kaya akan pertanian dan industry. Jumlah penduduk di Kabupaten
Karawang sebanyak 2.316.489 jiwa, dengan 1.129.215 jiwa penduduk perempuan dan 1.187.274 jiwa penduduk laki-laki. Kabupaten Karawang memiliki 21 Rumah Sakit, 50 Puskesmas, 65 Puskesmas Pembatu, 2.301 posyandu, 324 klinik, 123 apotek dan 
51 polindes yang tersebar di seluruh wilayah Kabupaten Karawang pada tahun 2017. Terdapat 2151 perawat, 1450 bidan, 33 perawat gigi, 59 ahli gizi dan 325 tenaga kefarmasian. Pada penelitian ini dilakukan pengambilan data kepada praktik mandiri bidan (PMB) di pedesaan dan perkotaan di Tabel 3 Perbandingan Tarif Asuhan Kehamilan antara Tarif di Pedesaan, Perkotaan dan Tarif BPJS

\begin{tabular}{llll}
\hline \multicolumn{1}{c}{ Tarif Asuhan Kehamilan } & $\mathrm{n}$ & Median (Minimum-maksimum) & Nilai P \\
& & & \\
\hline Tarif Non-BPJS di Pedesaan & 36 & 50k (30k-110k) & 0.011 \\
Tarif Non-BPJS di Perkotaan & 38 & 50k (30k-125k) & \\
Tarif BPJS & 37 & $50 \mathrm{k}(50 \mathrm{k}-50 \mathrm{k})$ & \\
\hline
\end{tabular}

Uji Kruskal-Wallis. Uji post hoc Mann-Whitney: Pedesaan vs Perkotaan $\mathrm{p}=0,054$, pedesaan vs BPJS $\mathrm{p}=0,783$, perkotaan vs BPJS $\mathrm{p}=0,002$

Berdasarkan hasil penelitian pada tabel 3 tentang tarif yang bayarkan oleh pasien kepada bidan untuk pelayanan kehamilan baik di pedesaan maupun diperkotaan memiliki median tarif yang sama. Hasil uji Statistik pada tabel 3
Kabupaten Karawang, didapatkan data 36 bidan di pedesaan dan 38 bidan di perkotaan, pengkategorisasian wilayah perdesaan dan perkotaan dibuat berdasarkan peraturan kepala Badan Pusat Statistik No 37 tahun 2010 (Statistik, 2018).

Tabel 4 Perbandingan Tarif Asuhan Persalinan antara Tarif di Pedesaan, Perkotaan dan Tarif BPJS

\begin{tabular}{lclc}
\hline \multicolumn{1}{c}{ Tarif Asuhan Persalinan } & $\mathrm{n}$ & Median (Minimum-maksimum) & Nilai P \\
& & & \\
\hline Tarif Non-BPJS di Pedesaan & 36 & $1.100 \mathrm{k}(700 \mathrm{k}-2.000 \mathrm{k})$ & 0.0001 \\
Tarif Non-BPJS di Perkotaan & 38 & $1.250 \mathrm{k}(800 \mathrm{k}-2.500 \mathrm{k})$ & \\
Tarif BPJS & 37 & $700 \mathrm{k}(700 \mathrm{k}-700 \mathrm{k})$ & \\
\hline Uji Kruskal-Wallis. Uji post hoc Mann-Whitney: Pedesaan vs Perkotaan $\mathrm{p}=0,0382$, pedesaan vs \\
BPJS p=0,0001, perkotaan vs BPJS p=0,0001
\end{tabular}

Sama halnya dengan tarif asuhan perkotaan dan pedesaan $(\mathrm{p}>0,05)$, namun kehamilan, pada asuhan persalinan di terdapat perbedaan tarif persalinan antara pedesaan dan di perkotaan tidak ditemuakan tarif di pedesaan dan BPJS $(p<0,05)$ serta perbedaan tarif yang signifikan, Hasil uji antara tarif di perkotaan dan tarif BPJS Statistik pada tabel 4 didapatkan bahwa tidak $\quad(\mathrm{p}<0,05)$. terdapat perbedaan tarif persalinan di Tabel 5 Perbandingan Tarif Asuhan Persalinan Disertai Penyulit antara Tarif di Pedesaan, Perkotaan dan Tarif BPJS 


\begin{tabular}{lclc}
\hline \multicolumn{1}{c}{$\begin{array}{c}\text { Tarif Asuhan Persalinan } \\
\text { dengan Penyulit }\end{array}$} & $\mathrm{n}$ & Median (Minimum-maksimum) & Nilai P \\
\hline Tarif Non-BPJS di Pedesaan & 36 & $1.550 \mathrm{k}(700 \mathrm{k}-3.500 \mathrm{k})$ & 0.0001 \\
Tarif Non-BPJS di Perkotaan & 38 & $1.825 \mathrm{k}(900 \mathrm{k}-3.000 \mathrm{k})$ & \\
Tarif BPJS & 37 & $950 \mathrm{k}(950 \mathrm{k}-950 \mathrm{k})$ & \\
\hline
\end{tabular}

Uji Kruskal-Wallis. Uji post hoc Mann-Whitney: Pedesaan vs Perkotaan $\mathrm{p}=0,815$, pedesaan vs BPJS $\mathrm{p}=0,0001$, perkotaan vs BPJS $\mathrm{p}=0,0001$

Pada tabel 5 didapatkan bahwa tidak terdapat perbedaan tarif persalinan yang disertai kondisi kegawatan antara di perkotaan dan pedesaan, namun terdapat perbedaan tarif yang signifikan persalinan yang disertai kondisi kegawatan antara tarif di pedesaan maupun di perkotaan dengan standar tarif BPJS kesehatan ( $>>0,05)$, dalam hal ini kondisi kegawatan yang ditatalaksana oleh bidan adalah kondisi yang harus dilakukan penatalaksanaan untuk mencegah terjadinya kematian pada ibu, seperti pada kondisi persalinan dengan perdarahan yang membutuhkan penanganan segera.

\section{PEMBAHASAN}

\section{Tarif Asuhan Kehamilan}

Tarif terendah asuhan kehamilan oleh bidan baik di pedesaan maupun di perkotaan di Kabupaten Karawang adalah sebesar Rp.30.000 sedangkan tarif tertinggi di pedesaan adalah 110.000 dan di perkotaan adalah 125.000, pelayanan yang diberikan oleh bidan pada setiap kali pemeriksaan kehamilan terdiri dari anamnesa, pemeriksaan fisik, pemberian vitamin tambah darah $(\mathrm{Fe})$ dan imunisasi $\mathrm{TT}$ jika dibutuhkan, sedangkan standar tarif yang dibayarkan oleh BPJS kesehatan untuk penggantian biaya kunjungan kehamilan adalah sebesar 50.000 untuk setiap kali kunjungan, besaran tarif tersebut dapat mencukupi ataupun dapat pula sangat kurang dari standar tarif normal bidan yang diberlakukan kepada pasien.

Perbedaan tarif tersebut disebabkan karena masyarakat perkotaan di Kabupaten Karawang memiliki pendapatan yang jauh lebih tinggi dibandingkan dengan masyarakat pedesaan, bedasarkan data Statistik, (2018) Kabupaten Karawang diketahui bahwa perputaran perekonomian masyarakat di perkotaan lebih tinggi dibandingkan dengan di pedesaan, hal tersebut dibuktikan dengan data bahwa sebanyak 33,13\% masyarakat Karawang bekerja di bidang perdagangan, 29,92\% di bidang industri dan hanya $14,18 \%$ bekerja di bidang pertaniaan (Statistik, 2018).

Pendapatan masyarakat diperkotaan berpengaruh terhadap tarif yang ditetapkan oleh BPM, masyarakat di pedesaan masih kental oleh pengaruh sosial budaya, yang terjadi di Kabupaten Karawang terdapat masyarakat yang masih memilih untuk memeriksakan dirinya di dukun bayi yang dianggap lebih murah dibandingkan dengan memeriksakan diri di Bidan. Selain itu BPM diperkotaan berlokasi di tempat yang 
strategis dan mudah terjangkau oleh pasien, seahingga dengan lokasi yang strategis tersebut dapan menjadi nilai jual bagi bidan agar dapat menetapkan tarif pelayanan yang lebih tinggi dibandingkan dengan di pedesaan, hal tersebut sejalan dengan penelitian Werdhani (2019) yang mengatakan bahwa aspek lingkungan merupakan hal yang dapat mempengruhi kondisi kesehatan seseorang, kondisi pedesaan dan perkotaan dalam akses kesehatan berbeda secara signifikan bahkan salah satunya dapat menyebabkan kematian ibu ataupun bayi yang disebabkan oleh rendahnya akses serta permasalahan sosial budaya di masyarakat (Werdhani, 2019).

\section{Tarif Asuhan Persalinan}

Nilai median tarif asuhan persalinan normal yang diberlakukan di pedesaan adalah sebesar Rp. 1.100.000,- sedangkan untuk diperkotaan adalah sebesar Rp. 1.250.000,-, adapun nilai median untuk tarif persalinan dengan penyulit di pedesaan adalah sebesar Rp.1.550.000,- dan diperkotaan sebesar Rp.1.825.000,-. Penetapan standar pembiayaan asuhan persalinan yang dikeluarkan oleh BPJS Kesehatan sangat jauh di bawah nilai median tarif di pedesaan maupun diperkotaan yaitu sebesar Rp.700.000,untuk persalinan normal dan Rp.950.000,untuk persalinan dengan penyulit.

Dampak dari pembiayaan yang jauh di bawah standar tersebut adalah dihilangkannya fasilitas penyediaan makan bagi pasien peserta JKN. Hal tersebut menjadi solusi bagi kedua belah pihak baik itu bidan maupun pasien untuk mengimplementasikan aspek keadilan dalam pembiayaan kesehatan. Pada dasarnya perlu pengkajian lebih lanjut mengenai hal ini, karena penurunan standar kualiatas pelayanan yang diberikan bidan kepada pasien JKN sebaiknya merupakan hal yang tidak boleh terjadi, akan tetapi bidan berada pada posisi sebagai pemberi pelayanan dan sebagai pengusaha yang tidak bisa mengenyampingkan aspek ekonomi dalam perjalanan bisnisnya.

Marhenta, Satibi and Wiedyaningsih (2018) dalam studinya tentang kualitas pelayanan BPJS di fasilitas kesehatan tingkat pertama di Kabupaten Karanganyar menunjukan bahwa pembiayaan dan pelayanan kesehatan yang diberikan berpengaruh secara signifikan terhadap tingkat kepuasan pasien (Marhenta et al., 2018).

Pembiayaan dalam suatu pelayanan kesehatan merupakan hal yang sangat penting bagi bidan, karena bidan merupakan tenaga professional yang berhak memberikan pelayanan kesehatan selama masa kehamilan, nifas, BBL dan KB. Hingga saat ini Bidan merupakan tenaga kesehatan dengan jumlah terbanyak ke 3 setelah dokter umum dan perawat di Kabupaten Karawang (Karawang, 2019). 
Bidan diharuskan untuk memberikan pelayanan kesehatan yang berkualitas, pemberian pelayanan yang berkualitas harus didukung oleh ketersediaan sarana dan prasarana yang memadai di fasilitas praktik bidan, karena hal tersebut Tenaga kesehatan merupakan salah satu unsur yang mempengaruhi terhadap pengetahuan dan perubahan perilaku pasien (Espich, 2007).

Tidak dapat dipungkiri pemberlakuan JKN di Indonesia dapat mengatasi permasalahan akses terhadap tenaga kesehatan saat persalinan bagi masyarakat dengan kondisi ekonomi menengah ke bawah, hasil kajian yang dilakukan oleh Brooks et al. (2017) di Indonesia tentang persalinan oleh tenaga kesehatan pada masyarakat miskin didapatkan hasil bahwa masyakat miskin yang menjadi peserta JKN lebih mungkin untuk dapat bersalin di fasilitas pelayanan kesehatan dan bersalin oleh tenaga kesehatan professional dibandingkan dengan masyarakat miskin yang tidak menjadi peserta JKN (Brooks et al., 2017).

Terdapat 1.028.526 ibu hamil di Jawa Barat dan 18,97\% diantaranya mengalami komplikasi, ibu hamil yang mengalami komplikasi tersebut dimungkinkan akan memiliki penyulit saat persalinan, oleh karena itu pendanaan kesehatan pada pasien disertai dengan penyulit persalinan merupakan hal yang sangat di butuhkan sesuai dengan kondisi kesehatan di Indonesia (Dinas Kesehatan Depok, 2016).

Melihat pada kondisi tarif asuhan persalinan pada tabel 4 dan 5 yang mana tarif asuhan persalinan yang dikeluarkan oleh BPJS Kesehatan masih jauh di bawah nilai median tarif asuhan persalinan di pedesaan maupun perkotaan selayaknya pemerintah Indonesia memberi perhatian yang lebih serius, karena hal ini berkaitan dengan tingginya angka kematian ibu dan bayi yang masih terjadi di Indonesia, pada tahun 2019 terdapat 306/100.000 kematian ibu dan 14/1.000 kematian bayi di Indonesia, penurunan standar kualiatas pelayanan yang diberikan oleh bidan bukan tidak mungkin dapat berkontribusi pada terjadinya kematian ibu ataupun bayi, meskipun hal tersebut perlu dipelajari lebih lanjut (Kementerian Kesehatan Republik Indonesia, 2019).

Pendanaan BPJS kesehatan di Indonesia sudah saatnya untuk ditingkatakan demi kesejahteraan pasien dan tenaga kesehatan yang memberikan pelayanan, saat ini bersumber dari iuran peserta, namun pada hasil riset yang dilakukan oleh Ahsan (2017) yang juga dipubliksikan oleh BPJS Kesehatan pada tahun 2017 bahwa BPJS Kesehatan memiliki peluang untuk meningkatkan pendanaan yang berasal dari pajak rokok (Ahsan, 2017).

Berbeda dengan Indonesia jika melihat realita yang terjadi di Nigeria bahwa 
pendanaan jaminan kesehatan bersumber dari anggaran pemerintah, pembayaran tambahan oleh pasien, pajak negara, sumbangan dari negara donor, asuransi kesehatan yang berasal dari pihak swasta, asuransi kesehatan berbasis masyarakat yang bersifat sukarela dan asuransi kesehatan swasta (Uzochukwu et al., 2015).

\section{KESIMPULAN}

Tarif yang telah ditentukan oleh BPJS Kesehatan untuk asuhan kehamilan tidak jauh berbeda dengan standar tarif asuhan kehamilan di pedesaan namun signifikan sangat berbeda dengan standar tarif asuhan kehamilan untuk di perkotaan, untuk tarif asuhan persalinan normal dan persalinan disertai kondisi kegawatan sesuai standar BPJS Kesehatan berbeda secara signifikan dengan tarif yang diberlakukan baik di perkotaan maupun pedesaan, bidan sebagai tenaga kesehatan perlu bekerja keras untuk dapat memberikan pelayanan yang optimal dengan pendanaan yang sub-optimaal. Pendanaan BPJS kesehatan di Indonesia sudah saatnya untuk ditingkatakan demi kesejahteraan pasien dan tenaga kesehatan yang memberikan pelayanan.

\section{DAFTAR PUSTAKA}

Ahsan, A. (2017). Ringkasan Riset JKNKIS. Jakarta.
Badan Pusat Statistik. (2018). Karawang Regency in Figures. Karawang: Badan Pusat Statistik.

Bapennas. (2017). Sustainable Development Goals. Retrieved February 28, 2019, from http://sdgs.bappenas.go.id

BPJS Kesehatan. (2017). Seputar BPJS Kesehatan. Retrieved March 1, 2019, from https://bpjskesehatan.go.id/bpjs/dmdocuments/ea c4e7a830f58b4ade926754f74b6caf.pd f

Brooks, M. I., Thabrany, H., Fox, M. P., Wirtz, V. J., Feeley, F. G., \& Sabin, L. L. (2017). Health facility and skilled birth deliveries among poor women with Jamkesmas health insurance in Indonesia: a mixedmethods study. BMC Health Services Research.

https://doi.org/10.1186/s12913-0172028-3

Dinas Kesehatan Depok. (2016). Profil Kesehatan Dinas Kesehatan Provinsi Jawa Barat 2016. Research.

Espich, J. E. (2007). Applying bloom's taxonomy of educational objectives. National Society of Programmed Instruction.

https://doi.org/10.1002/pfi.418003090 6

Gumelar, G. (2018). Pangkal "Penyakit" Defisit BPJS Kesehatan. CNN Indonesia, pp. 1-6. 
Indonesia, M. K. R. Standar Tarif Pelayanan

Kesehatan dalam Penyelenggaraan

Program Jaminan Kesehatan (2016). Indonesia.

Karawang, D. K. (2019). Profil Kesehatan Kabupaten Karawang. Karawang: Dinas Kesehatan Kabupaten Karawang.

Kementerian Kesehatan Republik Indonesia. (2019). Kesehatan Indonesia Menghadapi Revolusi Industri 4.0. Jakarta.

Marhenta, Y. B., Satibi, \& Wiedyaningsih, C. (2018). Pengaruh TIngkat Kualitas Pelayanan BPJS dan Karakteristik Pasien Terhadap Kepuasan Pasien di Fasilitas Kesehatan Tingkat Pertama. Journal of Management and Pharmacy Practice, 8(1), 18-23.

Molla, A. A., \& Chi, C. (2017). Who pays for healthcare in Bangladesh? An analysis of progressivity in health systems financing. International Journal for Equity in Health. https://doi.org/10.1186/s12939-0170654-3

Schröders, J., Wall, S., Hakimi, M., Dewi, F. S. T., Weinehall, L., Nichter, M., ... Ng, N. (2017). How is Indonesia coping with its epidemic of chronic noncommunicable diseases? A systematic review with meta-analysis. PLoS

ONE. https://doi.org/10.1371/journal.pone.0 179186

Seftiawan, D. (2018). Kenapa BPJS Kesehatan Defisit Triliunan Rupiah? Ini alasannya. Pikiran Rakyat, pp. 13. Retrieved from https://www.pikiranrakyat.com/nasional/2018/11/09/kena pa-bpjs-kesehatan-defisit-triliunanrupiah-ini-penjelasannya-432979

Uzochukwu, B. S. C., Ughasoro, M. D., Etiaba, E., Okwuosa, C., Envuladu, E., \& Onwujekwe, O. E. (2015). Health care financing in Nigeria: Implications for achieving universal health coverage. Nigerian Journal of Clinical Practice. https://doi.org/10.4103/11193077.154196

Werdhani, R. A. (2019). Medical problem in Asia pacific and ways to solve it: The roles of primary care/family physician (Indonesia Xperience). Journal of Family Medicine and Primary Care, $8(5)$, $1523-1527$. 
